\title{
KEARIFAN LOKAL PELA-GANDONG DI LUMBUNG KONFLIK
}

\author{
Hamzah Tualeka Zn \\ Fakultas Ushuluddin IAIN Sunan Ampel \\ Jalan Jend. A. Yani No. 117 Surabaya. Telp. 031-8438369/081330709787 \\ email: hamzahtualekazn@gmail.com
}

\section{Abstract}

Revitalization of pela-gandong has become urgent to shade a light in the misunderstanding surrounding this concept. This research is aimed at answering three questions: (1) how does the conflict happened in Ambon-Lease, (2) what are the root of the conflict, and (3) what are the best solution according to Ambonesse - Lease people perspective. This research is a field study which is also supported by library research. This research used qualitative method. Finding of this research has a theoretical implication concerning the concept of conflict and integration conflict based on the Lewis A. Coser and Karl Marx theory. This paper believes that there is a close relation between the concept of pela-gandong and the two theories. Findings of the research are expected to inspire other researchers conducting a dialectical theory analysis among Lewis A. Coser, Karl Marx theory and pela-gandong concept which, therefore, can be constructed as theoretical concept related to multi-dimensional conflict.

Key words: conflict, integration, pela-gandong,

\section{Abstrak}

Revitalisasi pela-gandong merupakan keharusan yang mendesak untuk dilakukan sebagai tebusan atas pemahaman miring dan apatis yang selama ini muncul. Penelitian ini ingin menjawab tiga permasalahan pokok: (1) bagaimana sebenarnya peristiwa konflik yang terjadi di Ambon-Lease, (2) apa akar permasalahannya, dan (3) bagaimana pola penyelesaian konflik dalam perspektif masyarakat Ambon-Lease. Penelitian ini merupakan studi lapangan yang ditunjang oleh penelitian literer (library research). Metode penelitian yang digunakan adalah pendekatan kualitatif. Temuan dari penelitian ini memiliki implikasi teoretik terhadap konsep konflik dan integrasi ala Lewis A. Coser dan dialektika Karl Marx. Terdapat benang merah antara konsep pela-gandong dengan dua teori di atas. Hasil penelitian ini diharapkan menjadi sumber inspirasi untuk melakukan dialektika antara pendekatan analitik teori Lewis A. Coser, Karl Marx dan konsep pela-gandong. Langkah selanjutnya, hal itu bisa dijadikan kerangka teoretik terkait dengan konflik multidimensional.

Kata kunci: konflik, integrasi, pela-gandong, Ambon-Lease 


\section{Pendahuluan}

Negara ditinjau secara historikal konstitusional, awal keberadaan negara bangsa Indonesia merupakan kesepakatan final dari para pendahulu pendiri negeri ini sebagai bentuk pengakuan terhadap pluralitas yang menjadi pilar tegaknya negara, dengan demikian Bhinneka Tunggal Ika menjadi payung hukum terakuinya kemajemukan tersebut.

Perjalanan sejarah anak-anak negeri Ambon-Lease, pluralitas telah melahirkan kolaborasi yang indah dalam berbagai bentuk mozaik budaya yang kental dengan kemajemukan tersebut. Berbagai suku, agama, ras adat istiadat, budaya dan golongan dapat hidup berdampingan dan memiliki ruang negosiasi yang tinggi dalam kehidupan sehari-hari dengan kearifan lokal pelagandong-nya. Pela-gandong ialah perserikatan antara satu negeri di pulau-pulau Ambon-Lease dengan satu atau beberapa negeri lain di pulau Seram, perserikatan didasarkan pada hubungan persaudaraan sekandung sejati, dengan isi dan tata laku perserikatan yang diatur dalam perjanjian baik lisan maupun tulisan, di mana para pihak berjanji untuk tunduk kepada perjanjian dimaksud sebagai dasar hukum bagi implementasinya dari waktu ke waktu (Lokollo, 1997: 5). Pelagandong lahir lima abad sebelum Marx, mengalami proses yang sama dengan konsep dialektika Karl Marx, bahwa kearifan lokal pela-gandong merupakan karya maksimal para leluhur AmbonLease, melalui tahapan paradigma lama monisme menuju dualisme dan final pada dialektika dan secara radikal menghasilkan budaya pela-gandong (Watloly, 2005: 95-105).

Keindahan masyarakat negeri katulistiwa ini pun menjadi kesaksian bagi dunia internasional. Problem akademik, mengapa Ambon-Lease dan Maluku yang selama ini menjadi percontohan bagi kerukunan beragama berubah menjadi lumbung konflik? Di mana peran pelagandong?

Konflik Ambon-Lease telah melibatkan berbagai suku, agama, ras, dan adat serta golongan, bahkan juga dari pusat (Jakarta) dan dunia turut mengambil bagian dalam peristiwa tersebut. Ada tiga hal pokok yang menarik untuk diteliti: (1) peristiwa-peristiwa terjadinya konflik sosial bernuansa agama di Ambon-Lease, (2) akar masalah konflik. (3) pola penyelesaian konflik dalam perspektif masyarakat Ambon-Lease

\section{Metode Penelitian}

Penelitian ini merupakan penelitian lapangan dengan objek kepulauan Ambon-Lease. Metode yang dipergunakan adalah fenomenologi, yakni dengan membaca gerak masyarakat 
Ambon-Lease dalam bahasa dan perilakunya. Karena itu, wawancara mendalam (in-depth interview) dan observasi langsung dilakukan dalam penelitian yang berkaitan dengan konflik dan integrasi sosial bernuansa agama di Ambon-Lease ini. Terdapat beberapa referensi yang dijadikan bahan pertimbangan dan informasi awal tentang kondisi di lapangan yaitu antara lain proposisi Lewis A. Coser yang menyatakan: in-group bertambah secara integral sebagai fungsi dari konflik dengan out-group; kekokohan konflik dan mempertahankan keseimbangan dan kekuasaan; ideologi dan konflik; konflik sebagai suatu indeks dari stabilitas; konflik yang realistik dan non-realistik; konflik menciptakan asosiasi dan persatuan dan Karl Marx dengan materialisme dialektikanya yang menegaskan bahwa materi menentukan ide (Coser, 1964: 33139).

Berdasarkan kajian pustaka tersebut, dapat dijelaskan posisi penelitian sebagai berikut: Pertama, di tengah-tengah studi tentang peristiwa terjadinya konflik sosial bernuansa agama di Ambon-Lease, penelitian ini memusatkan kajian pada kejadian pra konflik dan tahapan-tahapan konflik yang terdiri dari lima tahapan. Kedua, penelitian ini memfokuskan diri pada kajian tentang akar-akar konflik yang meliputi pemaknaan agama, bias sejarah, etnisitas, karakteristik sosial dan kepentingan-kepentingan. Ketiga, penelitian ini terkonsentrasi pada pola penyelesaian konflik dalam perspektif masyarakat, yakni kearifan lokal pela-gandong yang dimiliki secara turun-temurun dari leluhur mereka sejak dahulu kala.

Penelitian ini memilih lokasi di Ambon-Lease karena daerah ini dianggap tepat dan dapat mewakili daerah-daerah lain di Indonesia, atau setidak-tidaknya di Maluku, dengan beberapa pertimbangan. Pertama, perbandingan jumlah penganut agama Islam dan Kristen di AmbonLease rata-rata seimbang dan penuh dinamika. Kedua, di Ambon-Lease, baik umat Islam maupun Kristen, masing-masing memiliki proyek-proyek atau amal usaha (sekolah-sekolah, rumah sakit, panti asuhan dan lain-lain) dan tempat-tempat ibadah (masjid/mushalla/langgar dan gereja). Ketiga, kesadaran melaksanakan ajaran agama di kalangan umat Islam maupun Kristen cukup tinggi dibandingkan dengan daerah lain di Indonesia, daerah ini memiliki spesifikasi tersendiri, yaitu konsistensi terhadap komitmen pela-gandong masing-masing (Islam dan Kristen). Karena kentalnya satu sama lain hampir tidak mengetahui atau tidak mau tahu-menahu tentang kondisi saudara seagama di sebelahnya. Etnis BBM (Bugis, Buton, dan Makassar) tidak memiliki budaya pela-gandong namun terlibat dalam konflik, sementara pela-gandong belum difungsikan secara maksimal di lumbung konflik akibat terpaan dan himpitan yang membatasinya. Keempat, 
dengan beralihnya ekonomi dan politik ke tangan umat Islam, umat Kristen merasa terancam. Di sinilah konflik tersebut dapat digambarkan.

Penelitian ini bertumpu pada analisis data, yakni kegiatan mengolah fakta yang dikumpulkan dari lapangan dan pustaka sehingga menjadi seperangkat data. Tujuan analisis data adalah untuk membatasi penemuan dan data yang ada diatur lebih berarti. Kesimpulan bisa dilakukan dengan baik apabila data yang diperlukan sebagai dasar pengambilan keputusan diinformasikan secara tepat dan akurat. Langkah-langkah dalam penelitian ini bisa dirangkum sebagai berikut: (1) heuristik, yaitu usaha mencari dan mengumpulkan sumber-sumber; (2) kritik, yaitu kegiatan memberikan penilaian terhadap data serta menganalisis data dan sumber data; (3) interpretasi, yaitu menafsirkan keterangan dari berbagai sumber dan mensintesiskan hasil penafsiran tersebut dalam rangka pemikiran yang logis dan sistematis; dan (4) pelaporan, yaitu penulisan laporan penelitian yang dibuat dengan mengkonstruksi pemikiran berdasarkan fakta-fakta dan sumber data ke dalam bentuk tulisan yang objektif dan dapat dipertanggungjawabkan secara ilmiah.

\section{Hasil Penelitian}

\section{Persitiwa Konflik Ambon-Lease}

Dilihat pada tipologisnya, konflik sosial bernuansa agama di Ambon-Lease merupakan konflik horizontal. Namun, jika dilihat dari intensitas keterlibatan pelakunya dapat juga disebut sebagai konflik horisontal bernuansa vertikal.

\section{a. Pra Konflik}

Sebelum Tragedi Idul Fitri Berdarah pada tanggal 19 Januari 1999, terlebih dahulu terjadi penyerangan oleh warga Kristen terhadap perkampungan muslim Bugis, Buton dan Makassar (BBM) tanggal 12 November 1998 di Wailette. Penyerangan serupa terjadi lagi pada tanggal 27 Desember 1998 di kampung Bak Air. Terjadi juga serangan terhadap warga muslim di Dobo-Aru 14 Januari 1999 (Tualeka, 2010: 92). Pada awal Ramadan 1419 H terdengar isu akan ada gerakan pengusiran suku BBM dari Maluku, khususnya pulau Ambon, serta tersiar berita akan datang orang-orang kiriman dari Jakarta. Hal tersebut sangat menggelisahkan masyarakat.

\section{b. Tragedi Idul Fitri Berdarah}


Pada tanggal 1 Syawal 1419 H bertepatan dengan 19 Januari 1999, hari kemenangan umat Islam setelah sebulan penuh menunaikan ibadah puasa, suasana kota Ambon yang seharusnya menjadi wadah silaturahmi antar masyarakat dikotori oleh ulah sekelompok orang Kristen. Suasana kota Ambon mencekam karena terjadi serangan frontal dari berbagai penjuru. Peristiwa adu mulut antara Nursalim dan Yopy pukul 14.00 WIT berlanjut pada terjadinya perkelahian dan pembakaran dua rumah yang terletak antara Batumerah dan Mardika. Ada orang-orang misterius yang terlibat. Di sini alat picu konflik disulut. Pada pukul 16.30-21.00 WIB, aksi saling menyerang dan membakar rumah warga dan rumah ibadah terjadi (Tualeka, 2010: 94-95).

Terdapat dua versi pendapat yang menjelaskan tentang siapa yang benar dan siapa yang salah di antara Nursalim dan Yopy (Fatwa, 2007: 84-85). Versi pertama, versi tim pengacara Gereja yang diyakini kebenarannya oleh umat Kristen. Versi kedua, versi tim pencari fakta muslim Ambon yang diyakini kebenarannya oleh umat Islam. Masing-masing pihak mengklaim bahwa versinya-lah yang benar. Ketika The Human Right Watch mengkonfirmasi ke polisi, ternyata versi kedualah yang diterima. Muncul berita bahwa para pemicu itu bukan dari Batumerah dan bukan pula dari Mardika, akan tetapi preman-preman Ambon Jakarta yang sengaja dipulangkan dan dimobilisasi untuk menyulut kerusuhan di Ambon (Hilmy, 2004: 7273). Mereka berhasil menyulut alat pemicu konflik. Maka benarlah argumen Smelser, bahwa adanya faktor pemercepat atau pemicu suatu peristiwa dramatis atau desas-desus mempercepat munculnya perilaku kekerasan kolektif (Depag, 2003: 112-113).

Jika diperhatikan dengan seksama, peristiwa-peristiwa tersebut menandakan posisi umat Islam sebagai korban, sedangkan kaum Kristen sebagai pelakunya. Tragedi berdarah ini terkoordinir dengan rapi dan baik sekali, karena mampu memanfaatkan suasana dimana kebanyakan umat Islam di kota Ambon pulang kampung untuk merayakan Idul Fitri bersama keluarga. Tampak adanya benang-merah antara peristiwa-peristiwa pra konflik dengan Tragedi Idul Fitri Berdarah, yakni terdapat adanya konspirasi besar untuk menghancurkan umat Islam. Sementara itu, ada pihak lain yang menganggap tindakan tersebut merupakan sesuatu yang kondisional dan dilakukan karena semata-mata dorongan fakta di masyarakat yakni adanya peralihan dominasi kepada umat Islam, utamanya BBM dalam berbagai bidang kehidupan, yang semula berada di pihak kaum Kristen. Tuan tanah beralih ke tangan BBM, yang masuk ke Ambon-Lease sebagai transmigran sejak tahun 1970-an. 
Pada tahapan-tahapan konflik tersebut sering terjadi apa yang disebut sebagai kedahsyatan konflik atau konflik luar biasa, industri konflik dan commodity conflict (Hilmy, 2004: 74). Kedahsyatan konflik karena meningkatnya tensi konflik melebihi kejadian-kejadian serupa di mana pun di dunia ini. Banyak jatuh korban harta dan nyawa manusia dalam waktu yang singkat. Konflik terjadi dalam kurun waktu lama dan berlarut-larut, tak kunjung selesai.

\section{Akar-Akar Permasalahan Konflik}

\section{a. Pemahaman Miring terhadap Agama Lain}

Pertama, pandangan umat Islam. Semangat yang diajarkan dalam system of belief umat Islam Ambon-Lease adalah perilaku dalam interaksi sosial yang senantiasa harus dibatasi dengan sekat-sekat keimanan. Larangan bergaul secara intensif dengan orang Kristen dimaksudkan untuk melindungi keimanan anak-anak muslim. Dengan cara tersebut, iman anak-anak akan selalu terjaga dan tidak disusupi pemahaman atau keyakinan dari agama lainnya. Sebagai konsekuensi dari hal tersebut, misalnya, umat Islam memberikan simbol orang Kristen dengan “anjing" dan "babi”. Hal semacam ini tentu tidak ada pada mereka yang memilki hubungan pelagandong. Secara de facto, yang tidak memiliki pela-gandong adalah penduduk pendatang yakni BBM, Cina, Arab, Madura, Jawa dan lainnya (Hilmy, 2004: 76).

Biasanya, ketika penduduk pendatang itu hidup berdampingan dengan penduduk pribumi muslim, mereka aman-aman saja, akan tetapi, ketika mereka hidup berdampingan dengan penduduk asli (tuan tanah) Kristen, terjadilah suatu awal yang buruk, terlihat kontradiksikontradiksi dalam hal keyakinan beragama, dan pada akhirnya berdampak pada segi-segi kehidupan lainnya.

Pada sisi lain, ketika pandangan umat Islam seperti di atas dimiliki oleh penduduk asli, maka kondisi ini menunjukkan bahwa telah terjadi kelunturan nilai-nilai pela-gandong pada generasi muda di Ambon-Lease sekarang. Lalu, bagaimana dengan masa yang akan datang? Ataukah pandangan seperti di atas tidak bersumber pada umat Islam anak-anak negeri asli Ambon-Lease, melainkan pada etnis lain yang tidak memiliki budaya pela-gandong?

Kedua, pandangan kaum Kristen. Berbeda dengan pandangan dan semangat umat Islam, yang diajarkan dalam system of beliefs umat Kristen Ambon-Lease adalah sebuah perilaku dalam interaksi sosial yang senantiasa harus dibatasi dengan sekat-sekat keimanan menghadapi umat Islam (Hilmy, 2004: 79-80). Pertanyaanya: apakah terdapat sesuatu yang telah hilang dimakan 
modernitas? Secara kontekstual, ajaran absolutisme dan calvinisme cocok jika diterapkan di Barat, akan tetapi sangat tidak relevan jika diterapkan di Ambon-Lease, sebab realitas Barat memiliki titik interaksi keberagamaan yang bersifat homogen, sedangkan Ambon-Lease mempunyai nilai heterogenitas yang sangat tinggi. lnilah salah satu titik kelemahan dalam mengadopsi ajaran dan menginterpretasikan nilai-nilai ajaran Kristen secara tekstual, tanpa melihat segi kontekstualnya. Hal itu diperkuat oleh pemahaman sebagai umat terpilih di kalangan Kristen, diiringi dengan perilaku kompensasional politik kekuasaan kolonialis Belanda yang tercermin dalam perekrutan anak-anak sekolah dan pegawai-pegawai pada masa kolonialis Belanda, dimana faktor agama para calon (murid dan pegawai) menjadi pertimbangan utama-

yang tentu saja didominasi oleh orang Nasrani. Pemahaman sebagai umat terpilih ini, secara psikologis sangat memberi warna tersendiri bagi perilaku masyarakat Kristen. Al kitab berpesan, "Pergilah, jadikanlah sekalian bangsa sebagai murid-Ku dan baptislah mereka dalam nama Bapa dan Anak dan Roh Kudus" (Matius 28:19). Pesan ini layaknya pandangan umat Israel terhadap bangsa dan agama lainnya di muka bumi ini, seperti halnya semangat gerakan oikumene yang diperjungkan pihak GPM (Kruger, 1966: 91-93).

Pemahaman sebagai umat terbaik sah-sah saja, akan tetapi harus pula diimani bahwa kebenaran itu tidak hanya berada di satu pihak saja. Kebenaran ada di mana-mana dan tidak bisa dikatakan hanya oleh siapa pun. Itulah pemikiran cerdas terhadap realitas kehidupan dalam tataran heterogenitas agama, yang tidak bisa digeser begitu saja oleh ajaran tekstual agamaagama. Tuhan ada di mana-mana.

\section{b. Bias sejarah}

Secara historis kepulauan Ambon-Lease telah lama menjadi sentra kunjungan berbagai bangsa di dunia, baik dari Timur Tengah maupun dari Barat. Seiring dengan hal itu masuk juga agama Islam dan Kristen di wilayah ini. Pada zaman Portugis, Ambon-Lease telah menjadi sasaran incar, sejak jatuhnya Konstantinopel ke tangan bangsa Turki pada tahun 1453 dan kemudian diperkuat dengan program operasional penguasaan dunia oleh Portugis dan Spanyol. Akhirnya, Portugis tiba di objek sasarannya pada tahun 1511 M (Kruger, 1966: 15). Jika Kruger mengemukakan apa yang dikatakan seorang raja muda dari Goa bahwa orang-orang Portugis telah memasuki India dengan pedang di tangan kanan dan salib di tangan kiri, tetapi ketika mereka menemukan terlampau banyak emas, maka salib itu pun dilepaskan agar tangan-tangan 
mereka bisa mengisi saku dengan emas. Ucapan ini menjelaskan fakta sejarah bahwa pada mulanya agama betul-betul memainkan peranan. Akan tetapi, tujuan ekonomi dan politik makin lama semakin mendesak. Sebaliknya, pada zaman Belanda kepentingan agama bukanlah tujuan utama, melainkan politik dan ekonomi. VOC pun didirikan tahun 1605. Selanjutnya, tujuan agama diikutsertakan dan berlakulah semboyan "dimana VOC datang di situlah Gereja dibawa serta”. Rupanya berlaku semacam hukum rimba, bahwa siapa yang berkuasa dialah yang dapat menentukan segala sesuatu menurut kehendaknya. Jika pada zaman Portugis rakyat dipaksa menganut Kristen Katolik Roma, maka ketika Belanda berkuasa, orang-orang Islam dan sebagian yang sudah menganut Katolik Roma diharuskan pindah ke Kristen Protestan (Tualeka, 2004: 53).

Kenyataan tersebut merupakan pahatan sejarah pahit bagi rakyat tertindas, kaum muslimin. Harta, harga diri, hak asasi dan agama mereka selalu berada dalam ancaman. Sejarah Perang Pattimura telah menampakkan adanya kerjasama Islam-Kristen dan Ambon-Lease untuk melepaskan diri dari penindasan Belanda. Namun, pada hakikatnya ia adalah bagian dari rentetan perang antara Islam melawan penjajah tahun pada 1520-1817 (Tualeka, 2011: 162-163).

Catatan sejarah di atas tentu berbias dalam kehidupan sekarang dan muncul dalam aplikasi yang berbeda. Bagi kaum muslimin, masa lalu merupakan kenangan pahit dan trauma mendalam yang tidak pernah diharapkan terjadi kembali. Sementara bagi sebagian umat Kristen hal tersebut lebih banyak merupakan kenangan indah dan kerinduan kembali.

\section{c. Etnisitas}

Sebagaimana tersebut sebelumnya, penduduk Ambon-Lease kini terdiri dari beberapa etnis: Ambon-Lease asal, asli Ali Furu, Nusa Ina (artinya Pulau Ibu), Seram, Maluku, KeyTanimbar (Maluku), Arab, Cina, BBM (Bugis-Buton-Makassar), Jawa, Madura, Sumatera, Bali, Kalimantan dan lain-lain. Dari sekian etnis yang menghuni Ambon-Lease, BBM-lah yang merupakan etnis paling banyak mendapat sorotan dari lawan konflik. Kehadiran BBM di mata umat Islam tidak seberapa mendapat sorotan karena terdapat persamaan pada dasar ideologi. Meski secara teritorial telah banyak tuan tanah (kekuasaan) beralih ke tangan mereka. Itulah sebabnya mengapa umat Kristen melancarkan upaya besar-besaran dalam mengusir BBM. Karena kemajuan yang dicapai orang-orang BBM gilang-gemilang, hal itu mewujud sebagai ancaman terhadap dominasi kaum Kristen. 
Semestinya seluruh anak-anak negeri Salam-Sarani Ambon-Lease, sekaligus para rajarajanya, mengambil hikmah dari konflik dahsyat ini untuk menghidupkan kembali sistem pemerintahan raja dan latu pati yang pernah hilang di masa orde baru, serta melihat ulang masalah pertanahan yang sering menjadi sentra penyebab konflik.

\section{d. Karakteristik sosial}

Kekayaan alam Ambon-Lease telah membentuk sifat dan karakter sumber daya manusia yang lemah. Pada hakikatnya, pola berpikir anak-anak adat, anak-anak negeri Ambon-Lease, adalah kooperatif: antara faktor alam dan faktor sosial, sebagai ruh dari pela-gandong. Jika pada umumnya anak-anak negeri Ambon-Lease memiliki kondisi dan karakter sosial rendah, hal ini justru merupakan kondisi kontradiksi terhadap semangat pela-gandong itu sendiri.

Kemajuan yang dicapai para pendatang justru dinilai anak-anak negeri sebagai suatu ancaman serius bagi kehidupan perekonomian mereka. Seharusnya anak-anak negeri mau dan mampu mengintrospeksi diri, meninggalkan kebiasaan buruk yang selama ini membunuh kretivitas dan etos kerja mereka: mengapa mereka tidak mau jualan di pasar, tidak mau jadi tukang becak, menjadi buruh, pedagang kaki lima dan lainnya. Mereka justru menyalahkan, mengusir, dan membumihanguskan para pendatang. Tak bisa dipungkiri, kondisi seperti ini seringkali membuka peluang tejadinya konflik sosial antara pihak pendatang dengan pribumi.

\section{e. Kepentingan}

Sebenarnya, dengan daya tarik dan rayuan magnetnya, kepulauan Ambon-Lease telah lama menjadi incaran berbagai bangsa, baik dengan alasan kepentingan politik, ekonomi maupun agama. Seperti dikemukakan sebelumnya, tujuan semula Portugis datang ke Maluku adalah karena kepentingan misi salib, agama. Tetapi, tujuan-tujuan ekonomi dan politik makin lama semakin mendesak misi ini. Berbeda dengan Belanda yang semula tidak memiliki tujuan salib, melainkan murni tujuan politik dan ekonomi, tetapi kemudian menyusul kepentingan agama. Mereka meraih keuntungan dan sukses dengan meninggalkan luka dan trauma panjang bagi kaum muslimin Ambon-Lease, serta menarik kaum Kristen Ambon-Lease keluar dari rasa cinta budaya sendiri pela-gandong, digantikan oleh budaya Barat.

Di masa orde baru, penguasa telah melakukan berbagai kebijakan dalam bidang politik, misalnya, yang berdampak pada sisitem pemerintahan lokal. Sistem raja, latu pati digantikan 
kepala desa. Demikian pula kebijakan dalam bidang ekonomi yang diganti dengan LKMD dan BPC, menyebabkan banyaknya rakyat menderita karena "pohon uang rakyat", cengkeh, yang harganya merosot tajam sehingga Gubernur Maluku saat itu, Muhammad Akip Latuconsina, mengekspresikannya dengan tangisan untuk menangisi nasib rakyatnya. Kondisi ini tidak hanya menimpa salah satu kelompok agama tertentu, Islam atau Kristen, akan tetapi kedua-duanya sama-sama merasakan penderitaan akibat kebijakan tersebut. Benar kata para orang tua di negeri ini, mengapa sebutan bunga raja untuk cengkeh berubah menjadi po' lawan atau po' rawanno yang artinya "bunga yang menimbulkan perlawanan dan peperangan". Begitulah, kepentingan pemerintah orde baru justru menambah kesempurnaan penderitaan rakyat.

\section{f. Pola Penyelesaian Konflik Perspektif Masyarakat}

Upaya integrasi atau rekonsiliasi untuk meredakan konflik Ambon-Lease sudah beberapa kali dilaksanakan oleh berbagai pihak (pemerintah pusat, pemerintah daerah, DPR, pakar akademisi perguruan tinggi, komnas HAM, LSM, dan lainnya). Hampir semua hasil dari usahausaha itu belum atau tidak dapat diketahui oleh masyarakat luas, kecuali hanya sedikit sekali seperti implementasi hasil perdamaian Maluku di Malino.

Dalam kurang lebih sepuluh kali upaya rekonsiliasi, perwakilan dari kedua belah pihak yang bertikai, yakni anak-anak negeri Ambon-Lease telah dilibatkan. Mereka sadar bahwa resolusi-resolusi yang melibatkan mereka belum sepenuhnya menyentuh cara-cara damai yang agamis dan adatis. Di sini belum tampak adanya upaya memasukkan pela-gandong sebagai referensi dalam perdamaian di tanah kelahirannya sendiri, karena masih terdapat adanya kendalakendala yang telah terbangun secara sistematik sejak lama, baik secara eksternal maupun internal.

Maksud dari pola penyelesaian konflik perspektif masyarakat Ambon-Lease tidak lain adalah kearifan lokal pela-gandong. Cara seperti ini telah memiliki akar dan dilaksanakan masyarakat Ambon sejak ratusan tahun silam, diawali para leluhur dan kemudian secara turuntemurun berlaku sampai sekarang. Kehadiran dan perkembangan sistem pela-gandung telah teruji ketika mengalami gelombang dinamika kehidupan sosial yang kental dengan perubahan. Realitas sejarah menunjukkan bahwa sistem pela-gandong tidak hanya mampu mendamaikan problematika kehidupan masyarakat, tetapi juga pernah jatuh bangun dalam himpitan modernisasi sosial, politik, ekonomi dan agama di negeri ini. 
Pela-gandong pernah menghiasi sidang-sidang kongres pemuka-pemuka ahli ilmu perbandingan agama dunia, dimana ia dijadikan sebagai salah satu referensi dalam pembahasan tentang toleransi kehidupan antar umat beragama di dunia (Tualeka, 2004: 65). Dengan melaksanakan adat pela-gandong, maka selama kurang lebih lima abad Ambon-Lease tidak pernah tergoncang konflik hebat, sekalipun memiliki potensi konflik yang tinggi. Ketika caracara damai menurut berbagai versi tak juga mampu mendamaikan, maka yang dinanti adalah kehadiran dan kemujaraban pela-gandong. Sebagai contoh, dalam menghadapi penyelesaian kasus konflik Ambon-Lease, dengan keadaan terseok-seok akibat himpitan modernitas, ternyata pela-gandong tetap eksis dan mampu berperan.

Pela-gandong pernah jatuh bangun dalam himpitan modernitas sosial politik, ekonomi dan agama. Dengan alasan demi persatuan dan kesatuan bangsa serta stabilitas nasional, semua perkara harus berada di bawah pengawasan dan pengendalian pihak yang berwajib, dalam hal ini pemerintah atau penguasa. Tak sedikit pengorbanan rakyat akibat dari implementasi peraturan pemerintah seperti ini, termasuk PP No. 5 Tahun 1975 yang secara nyata, menghapus sistem pemerinatahan raja dan latu pati dengan kepala desa. Padahal, sesungguhnya ia merupakan keterkaitan (satu paket) dengan sistem kekerabatan pela-gandong (sebagai faktor eksternal, dari luar anak-anak negeri Ambon-Lease). Secara internal, dalam perjalanannya pela-gandong pernah mendapat gangguan berat justru dari anak-anak negeri Ambon-Lease sendiri karena dianggap menghalangi jalannya ekspansi agama yang diamanatkan kepada mereka.

Jika ditelaah secara cermat, sesungguhnya di satu sisi tradisi pela-gandong dapat memelihara kegerejaan ratusan tahun lamanya, namun di sisi lain pela-gandong pulalah yang tidak memungkinkan berkembangnya kegerejaan di dalam suatu usaha yang hidup. Menurut kaum Kristen, atau sebagian mereka, secara sosiologis psikologis adat pela-gandong dianggap sebagai sesuatu yang menghambat jalan dan lancarnya kristenisasi di Ambon-Lease dan sekitarnya. Hampir tak terpikirkan bahwa tidak terjadinya konflik antara umat Islam dan Kristen adalah berkat suci dari sistem pela-gandong yang telah menjaga dan melindungi mereka dari konflik. Memang ada pihak-pihak yang tidak setuju dengan pendekatan sistem pela-gandong. Ada juga pihak muslim yang menganggap sistem pela-gandong bukanlah produk Nabi dan Allah SWT, sehingga dianggapnya suatu bid'ah dan harus dihindari. Padahal, mereka tidak menemukan pemikiran lain yang lebih produktif dan efektif dalam proses perdamaian, guna 
mengangkat harkat dan martabat umat Islam sebagai rahmatan li al- 'alamin, sebagai rahmat bagi semesta alam.

Berbagai informasi yang ada di lapangan melahirkan optimisme bahwa sistem pelagandong saat ini masih berperan penting, terutama di daerah Maluku Tengah. Karena rasa persatuan dan identitas bersama disadari dan dihayati dengan kuat dalam upacara-upacara pembaharuan pela (melalui upacara panas pela) yang masih sering berlangsung. Sejak perang Dunia II, sejumlah pela baru diadakan dengan sadar untuk menguatkan hubungan antara dua golongan itu. Dapat dikatakan bahwa berkat sistem pela-gandong itu, pertentangan antara muslim dan umat Kristen yang terjadi pada tahun 1998-2002 dapat diredam. Berkat pelagandong tak sedikit calon-calon korban (yang terdapat dalam daftar orang akan dibunuh) akhirnya selamat dari rencana-rencana jahat karena lebih dahulu mendapat informasi sebelum kejadian datang menimpanya. Itulah beberapa peranan pela-gandong sebelum terjadinya Tragedi Idul Fitri Berdarah di Ambon-Lease tanggal 19 Januari 1999.

Pada saat konflik terjadi, pela-gandong tetap berfungsi dan efektif, sehingga sekat-sekat perbedaan agama tidak sampai menembusnya. Anak-anak negeri Ambon-Lease terkenal temperamental, apalagi jika ada panggilan untuk "perang salib" dan sabil. Jika sudah dibunyikannya genderang perang, maka darah pun tumpah. Sejarah membuktikan bahwa tidak ada perang antara dua bangsa yang memiliki hubungan pela-gandong di saat konflik AmbonLease terjadi pada tahun 1999-2002. Seandainya perekat itu tidak ada, atau tidak berfungsi sama sekali, maka sudah tentu tensi konflik akan lebih dahsyat lagi daripada peristiwa satu dasa warsa sebelumnya.

Simak sejarah bagaimana negeri Wai (Kristen) yang hendak direlokasi harus mendapatkan satu syarat, yaitu mendapatkan legitimasi dari negeri sebelahnya (tetangganya), negeri Tulehu (Islam) karena kasus konflik. negeri Wai memiliki hubungan pela-gandong dengan negeri Liang (Islam). Ketika persoalan relokasi negeri Wai diangkat ke permukaan untuk diselesaikan, terdapat kesepakatan kerjasama antara Tulehu dan Liang (sesama Islam). Atas permohonan raja dan masyarakat Liang kepada raja dan masyarakat Tulehu, keinginan mendapatkan persetujuan relokasi pela-nya, negeri Wai, dikabulkan pihak Tulehu. Kasus ini merupakan salah satu contoh dimana terdapat dua referensi yang digunakan sekaligus, yakni agama dan adatis (pelagandong). 
Aziz Tunny mengemukakan hasil penelitian dan rasa optimisnya terhadap peranan pelagandong, bahwa semakin hari ruang untuk rekonsiliasi semakin tercipta (Tunny, 2006: 5). Segregasi antar wilayah yang tadinya memisahkan dua komunitas penduduk sekarang sudah semakin terbuka. Lebih dari itu, khazanah budaya peninggalan para leluhur, pela-gandong, semakin merekatkan tali silaturahmi yang sempat terputus. Penyembuhan luka batin setelah konflik berlangsung secara alamiah atas inisiatif masyarakat karena adanya kekerabatan atau persaudaraan itu. Pela-gandong mengandung arti hubungan kekerabatan meski berbeda agama. Dapat pula diartikan hidup berdampingan dengan penuh tenggang rasa dalam perbedaan agama,, tetapi tidak saling mempengaruhi untuk masuk dan memeluk suatu agama tertentu. Perasaan seperti Tunny ini banyak dimilki anak-anak negeri Ambon-Lease, baik yang berdomisili di Ambon-Lease maupun yang ada di negeri rantau.

Bahkan seorang presiden Amerika Serikat, Barack Obama, merasa kagum terhadap keamanan yang terjadi di Ambon-Lease dan Maluku pasca konflik satu dasa warsa silam. Kekagumannya itu diaplikasikannya dalam bentuk pencarian fakta dengan mengutus empat anggota komisi nasional untuk kebebasan beragama Amerika Serikat yang dipimpin oleh Michael Cromartie, dengan anggota Scott Flipse, David Dettoni dan David Phelps. Mereka berkunjung ke Ambon pada tanggal 18 Mei 2010. Menurut tim tersebut, informasi yang diperoleh akan mereka sampaikan sebagai masukan kepada Kongres Amerika Serikat dan Gedung Putih, dengan harapan penanganan konflik dan kekerasan di Ambon-Lease bisa dijadikan model dalam menangani konflik dan kekerasan di beberapa negara yang masih bertikai (Jawa Pos, 19 Mei 2010: 11). Kontribusi positif terhadap perdamaian dunia akan cukup berarti manakala revitalisasi pela-gandong dapat segera diwujudkan.

\section{Simpulan}

Konflik sosial bernuansa agama di Ambon-Lease yang terjadi tanggal 19 Januari 1999 dikenal dengan Tragedi Idul Fitri Berdarah. Sebelumnya, terjadi konflik di tiga tempat yang berbeda sebagai uji coba oleh pihak penyerang, disusul beberapa kali tahapan dengan melibatkan masa kedua belah pihak dalam jumlah besar. Konflik ini disebut dahsyat, dan bahkan terdahsyat dibanding daerah lain di Indonesia, karena banyaknya korban, lamanya konflik, dan pihak-pihak yang terlibat, sehingga secara tipologi konflik sosial bernuansa agama di Ambon-Lease dapat dikategorikan sebagai "konflik horizontal bernuansa vertikal". 
Akar masalah konflik Ambon-Lease teridentifikasi pada motif-motif pemaknaan agama, bias sejarah, etnisitas, karakter sosial dan kepentingan. Semua itu mengkristal pada dua hal pokok, yakni kepentingan ekonomi dan politik. Di sini tidak ada perang agama, karena tidak ada agama apapun yang mengajarkan apalagi memerintahkan konflik. Namun, perubahan sosial merupakan suatu keniscayaan. Isu Nursalim dan Yopy di Batumerah dan Mardika hanyalah desas-desus sebagai pemicu konflik belaka.

Sebagai pola integrasi wasiat dan warisan para leluhur dalam penyelesaian konflik di Ambon-Lease, pela-gandong sesungguhnya masih eksis, efektif dan berfungsi sebagai katup konflik. Tetapi, kemampuannya tidak semaksimal yang diharapkan karena pela-gandong sendiri menjadi korban himpitan multidimensi modernitas. Salah satu hikmah besar konflik adalah timbulnya kesadaran mendalam bagi kedua belah pihak untuk kembali bekerjasama dan bersinergi merevitalisasi pela-gandong, guna menghadapi tantangan global di era kontemporer.

Ada beberapa implikasi konflik sosial bernuansa agama terhadap kerukunan hidup beragama di Ambon-Lease. Di antaranya, telah terjadi perubahan sosial di kalangan masyarakat pasca konflik yang salah satunya tercermin dalam gerakan panas pela (bekerjasama dan bersinergi merevitalisasi pela-gandong) untuk kembali memfungsikan pela-gandong sebagai alat perekat dan katup pengaman konflik.

Temuan penelitian ini memiliki implikasi teoretis terhadap konsep konflik dan integrasi ala Lewis A. Coser, di satu sisi mendukung dan di sisi lain mempertanyakan. Dalam hal mendukung, ada beberapa alasan. Pertama, bahwa kekuatan solidaritas internal dan integrasi ingroup kedua kelompok yang bertikai (Islam dan Kristen) semakin bertambah karena tingkat permusuhan dengan out-group bertambah besar. Terjadi ikatan dan hubungan kerjasama (dalam konflik dan integrasi). Konflik dapat berfungsi menciptakan asosiasi dan persatuan. Sistem pelagandong sebagai katup pengaman berlatar belakang konflik, yang dalam perjalanannya mengalami tekanan dan berujung kepada terjadinya konflik ulang. Bandingkan dengan konsep dialektika Karl Marx. Pela-gandong merupakan karya maksimal para leluhur Ambon-Lease, Maluku, melalui tahapan paradigma lama monisme menuju dualisme dan berakhir pada dialektika, dan secara radikal menghasilkan budaya pela-gandong.

Kedua, tentang konflik yang realistic dan non-realistic, serta ideology dan conflict. Konflik Ambon-Lease kental dengan indikator-indikator tersebut, dan termasuk dalam faktor- 
faktor yang menjadikan konflik berkepanjangan, berlarut-larut, serta sulit dalam penyelesaiannya.

Ketiga, menurut Coser, konflik merupakan suatu indeks dari stabilitas hubungan. Maka, konflik dengan out-group meningkatkan kohesi internal in-group, kekokohan konflik dan mempertahankan keseimbangan kekuasaan. Konflik Ambon-Lease berindikasi adanya upaya pihak-pihak penguasa sebagai in-group dalam mempertahankan statusnya, out-group dibuat tak berdaya. Adanya provokator yang bergentayangan sebelum dan pada saat terjadinya konflik Ambon-Lease, merupakan indikasi adanya sebuah konspirasi pihak tertentu. Mencari musuh, melempar batu sembunyi tangan, adanya pejabat terlibat, pertanda konflik in-group bisa kerjasama dengan out-group secara rahasia atau terang-terangan demi in-group. Teori Coser tentang pemeliharaan konflik guna melanggengkan kekuasaan pihak penguasa teridentifikasi muncul dan berulang kali terjadi di sini.

Keempat, jika kristalisasi teori Coser bahwa tidak selamanya konflik itu berkonotasi negatif, akan tetapi dapat pula berfungsi menghadirkan integrasi pada pihak-pihak yang berkonflik, maka di sini pela-gandong lebih berpeluang untuk dihadirkan kembali dan berfungsi dalam kehidupan bersama anak-anak negeri Ambon-Lease.

Dalam hal mempertanyakan, sekalipun terdapat benang merah antara konsep konflik dan integrasi Coser dan dialektika Marx dengan konsep pela-gandong, namun tetap aja tidak terjawab mengapa terjadi korban solusi konflik dan tipe konflik horisontal bernuansa vertikal untuk kasus Ambon-Lease. Merujuk pada rangkaian analisis konflik Coser, ketidakseimbangan yang terjadi pada integrasi bagian-bagian sistem akan membawa pada pecahnya berbagai tipe konflik di antara bagian-bagian tersebut, melampaui batas teori konflik Coser, sebagai suatu keadaan yang membahayakan sekalipun pada gilirannya secara temporer akan mengutuhkan kembali integrasi sistem dimana hasil akhirnya melahirkan keluwesan dan kesanggupan untuk mengatasi ketidakseimbangan dan kapasitas untuk menyesuaikan diri dengan lingkungan yang sedang berubah. Sebaliknya, hal tersebut dapat dijadikan sumber inspirasi untuk melakukan pendekatan analisis terhadap pemikian Coser, Karl Marx dan konsep pela-gandong, dan pada selanjutnya dijadikan sebagai kerangka teoretis tentang konflik multi dimensional. 


\section{Daftar Pustaka}

Coser, Lewis A. 1964. The Functions of Social Coflict. New York: A Division of Macmillan Publishintg Co. Inc.

Depag. 2003. Konflik Sosial Bernuansa Agama di Indonesia. Jakarta: Departamen Agama RI.

Fatwa, Achmad Fajruddin. 2007. Jembatan Hukum Islam Menyikapi Kekerasan Atas Nama Agama. Qualita Ahsana. Volume IX, Nomor 1: 77-92 .

Hilmy, Masdar at al. 2004. Membedah Anatomi Konflik Agama-Etnik: Rekonstruksi Paradigma Teori dan Resolusi Konflik Agama Etnik PascaOrde Baru. Surabaya: Lembaga Penelitian IAIN Sunan Ampel.

Jawa Pos. 19 Mei 2010. Kagumi Keamanan, Kecewa Dewan, Komisi Nasional Kebebasan Beragama AS Saat Berkunjung ke Ambon.

Kruger, Muller. 1966. Sejarh Gereja di Indonesia. Jakarta: Balai Penerbit Kristen.

Lembaga Biblika Indonesia.1974. Kitab Suci Perjanjian Baru. Ende: Percetakan Arnoldus.

Lokollo, J.E. at.al.1997. Seri Budaya Pela-Gandong dari Pulau Ambon. Ambon: Lembaga Kebudayaan Daerah Maluku.

Tualeka, Hamzah. 2004. Penyebaran dan Perkembangan Kristen di Ambon-Lease. Surabaya: Alpha.

Tualeka, Hamzah. 2010. Konflik dan Integrasi Sosial Bernuansa Agama, Studi tentang Pola Penyelesaian Konflik dalam Persfektif Masyarakat (disertasi). Surabaya: Program Pascasarjana IAIN Sunan Ampel.

Tualeka, Hamzah. 2011. Elemen-Elemen Pokok Dawah Islamiyah. Jakarta: Bintang Multiware.

Tunny, Aziz. 5 Maret 2006. Nadi Toleransi di Lumbung Konflik, Pela-Gandong Salam-Sarane, source: http://www.geocities.com/lokkie2005/rvp070306.htm.

Watloly, Aholiab. 2005. Maluku Baru Bangkitnya Mesin Anak Negeri. Yogyakarta: Kanisius. 